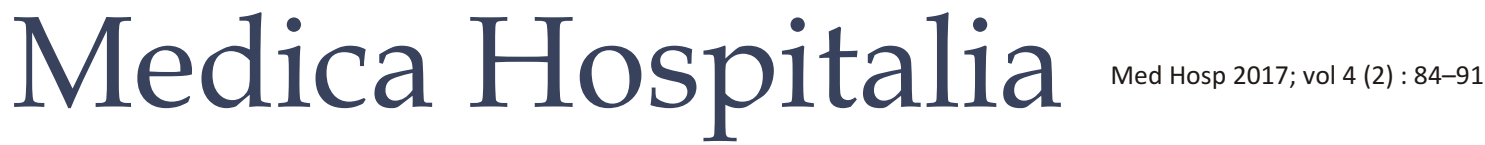

Original Article

\section{Pengaruh Pemberian Suplementasi Zink Terhadap Kadar Albumin Serum dan Hemoglobin Pada Lansia}

\author{
Meutia Setyowati Mahanani Lestari ${ }^{1}$, Erwin Prasetyo Ardy ${ }^{1}$, \\ Dwi Ngestiningsih², Amallia N Setyawati ${ }^{2}$
}

\author{
${ }^{1}$ Mahasiswa Program Profesi Pendidikan Dokter Fakultas Kedokteran Universitas Diponegoro \\ ${ }^{2}$ Staf pengajar di Program Studi Pendidikan Dokter di Fakultas Kedokteran Universitas Diponegoro
}

\begin{abstract}
Abstrak
Latar belakang : Lansia rentan mengalami penurunan albumin dan hemoglobin akibat defisiensi nutrisi, degenerasi organ, serta peningkatan oksidan dalam tubuh. Zink adalah mikromineral esensial yang berperan sebagai kofaktor enzim, hepatoprotektor, antioksidan serta penyusun ALA dehydrogenase, sebuah metalloenzim penting pada sintesis heme. Pemberian suplementasi zink diharapkan dapat meningkatkan kadar albumin dan hemoglobin lansia. Penelitian ini bertujuan untuk membuktikan pengaruh pemberian suplementasi zink terhadap kadar albumin dan hemoglobin serum pada lansia

Metode : Penelitian ini merupakan penelitian eksperimental dengan pre and post test control group design. Sampel adalah lansia berusia diatas 60 tahun yang tinggal di Unit Rehabilitasi Sosial Pucang Gading Semarang. Sebanyak 31 lansia yang setuju mengikuti penelitian dan memenuhi kriteria inklusi dan eksklusi dibagi secara acak menjadi dua kelompok. Kelompok perlakuan (16 orang) diberi suplemen zink $40 \mathrm{mg}$ perhari dan senam lansia, sedangkan kelompok kontrol (15 orang) diberi plasebo dan senam lansia. Pemberian suplementasi dilakukan setiap hari selama delapan minggu sedangkan senam lansia dua kali seminggu selama delapan minggu. Sebelum dan setelah penelitian, dilakukan analisa kadar albumin dan hemoglobin serum. Uji statistik menggunakan Wilcoxon dan paired t-test.

Hasil : Kadar albumin pada kedua kelompok penelitian mengalami kenaikan. Pada kelompok perlakuan kadar albumin meningkat sebesar $0,5 \pm 0,23 \mathrm{~g} / \mathrm{dL}(p<0,001)$ sedangkan pada kelompok kontrol meningkat sebesar $0,2 \pm 0,61 \mathrm{~g} / \mathrm{dL}(p=0,175)$. Peningkatan hemoglobin hanya ditemukan pada kelompok perlakuan, yaitu sebesar 0,7 $\pm 0,14(p=0,002)$. Pada kelompok kontrol, kadar hemoglobin turun sebesar $0,2 \pm 0,66(p=0,667)$.

Simpulan : Pemberian suplementasi zink dapat meningkatkan kadar albumin dan hemoglobin serum lansia.
\end{abstract}

Kata kunci : Penuaan, lansia, zink, albumin, zink

\section{Effect of zinc supplementation \\ on serum albumin level and hemoglobin in elderly}

\begin{abstract}
Background : In elderly, physical decrement condition tends to one of the vulnerable conditions that occur is a decrease of hemoglobin and albumin serum levels. Those changes, might alter albumin homeostatic level in elder population due to nutrient intake insufficiency, organs degeneration, and oxidation. Zinc was an essential trace element which functioned as co-factor of enzymes, liver protector, antioxidant, and composer of enzyme ALA dehydrogenase, ametalloenzim in hemesynthesis. We suspected zinc supplementation would enhance elder's serum albumin and haemoglobin. This study was to determine the effect of zinc supplementation on serum albumin and haemoglobin levels in elder populations.

Methods : In this randomized control trial, with pre and post-test control group design, we included 31 elder people who met inclusion-exclusion criteria and lived in Unit Rehabilitasi Sosial Pucang Gading Semarang. Samples were randomly divided into two groups. Treatment group (16 people) were daily supplemented with $40 \mathrm{mg}$ zinc and twice a week of exercise treatment, whereas control group (15 people) were placebo supplemented and got exercise treatment at same amount as treatment group. Both treatment last for 8 weeks. Albumin level analysis was performed before and after the trial. The data was then evaluated with Wilcoxon and Paired t-test.

Results : Treatment group resulted in significant increase albumin level by $0.5 \pm 0.23 \mathrm{~g} / \mathrm{dl},(p<0.001)$ while the control group increase by $(0.2 \pm 0.61 \mathrm{~g} / \mathrm{dl}, p=0.175)$. The enhancement of hemoglobin finds in treatment group only $0.7 \pm 0.14(p=0.002)$. In control group, hemoglobin decrease by $0.2 \pm 0.66(p=0.667)$.

Conclusions : Zinc supplementation could improve serum albumin level and hemoglobin on elder subject.
\end{abstract}

Keywords : elderly, zinc, albumin, hemoglobin 


\section{PENDAHULUAN}

Pertumbuhan populasi lansia semakin pesat seiring dengan terjadinya peningkatan usia harapan hidup penduduk Indonesia. ${ }^{1}$ Tantangan terpenting dalam menyikapi ledakan populasi lansia adalah dengan implementasi konsep menua sehat (healthy aging). Namun lansia rentan mengalami penurunan albumin dan hemoglobin akibat defisiensi nutrisi, degenerasi organ, serta peningkatan oksidan dalam tubuh. Penurunan kadar albumin dan hemoglobin diketahui menyebabkan gangguan kesehatan serta meningkatkan mortalitas dan morbiditas penderitanya. ${ }^{2}$ Penurunan kadar albumin juga dapat terjadi pada kondisi stres oksidatif, yaitu kondisi dimana terjadi ketidakseimbangan antara radikal bebas dan antioksidan akibat proses menua. ${ }^{3}$ Zink adalah mikro mineral esensial yang berperan sebagai kofaktor enzim, hepatoprotektor, antioksidan serta penyusun ALA dehydrogenase, sebuah metalloenzim penting pada sintesis heme. ${ }^{4,5}$ Pemberian suplementasi $\mathrm{Fe}$ secara luas digunakan untuk memperbaiki profil hemoglobin namun pemberian suplementasi zink belum banyak digunakan dapat memperbaiki profil hemoglobin serta albumin serum padalansia.

Pemberian suplementasi zink diharapkan dapat meningkatkan kadar albumin dan hemoglobin lansia.

\section{METODE}

Penelitian ini merupakan penelitian eksperimental dengan Randomized Control Trial (RCT). Subjek penelitian adalah 16 orang lansia dengan besar sampel minimal 12 orang, berusia 60 tahun keatas dan tinggal di Unit Rehabilitasi Sosial, Pucang Gading, Semarang. Penelitian dilakukan selama delapan minggu, pada bulan April-Mei 2015.

Sebelum dilakukan pemberian suplementasi zink, dilakukan screening berdasarkan kriteria inklusi-ekslusi, yaitu: berusia diatas 60 tahun, sehat secara fisik dan mampu melaksanakan aktivitas sehari-hari secara mandiri, tidak menderita gangguan jiwa berat dan penyakit terminal, tidak merokok, mengkonsumsi alcohol, tidak menderita gangguan pencernaan, seperti diare dan inflammatory bowel disease, tidak mendapat suplementasi besi, tembaga dan kalsium, serta bersedia

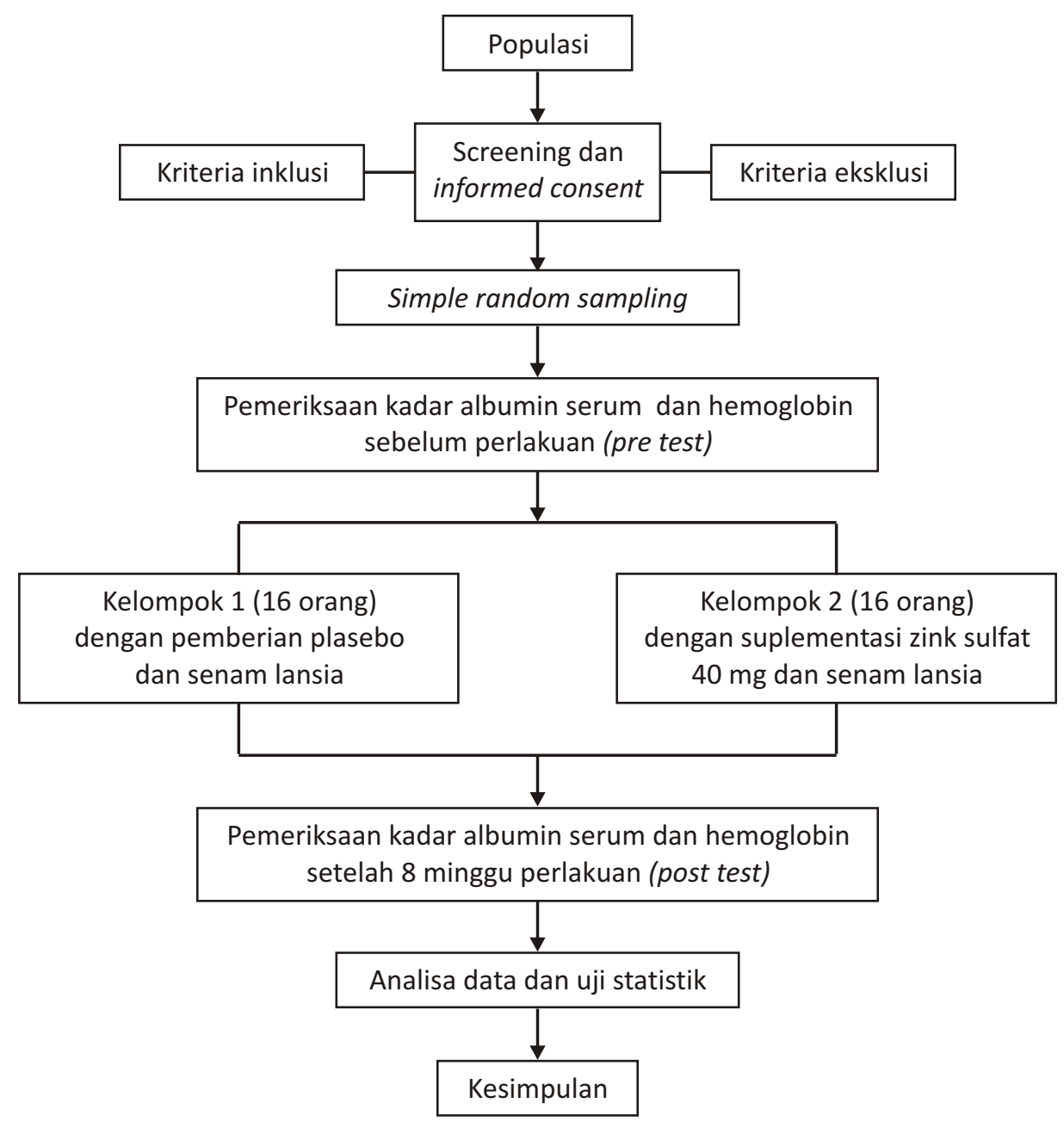




\section{TABEL 1}

Karakteristik subjek penelitian

\begin{tabular}{|c|c|c|c|}
\hline Variabel & $\begin{array}{l}\text { Perlakuan } \\
(n=16)\end{array}$ & $\begin{array}{l}\text { Kontrol } \\
(n=12)\end{array}$ & $p$ \\
\hline \multicolumn{4}{|l|}{ Kategori Usia } \\
\hline $60-65$ tahun & $3(18,8 \%)$ & $3(25,0 \%)$ & $0,1^{*}$ \\
\hline 66-70 tahun & $6(37,5 \%)$ & $2(16,7 \%)$ & \\
\hline 71-75 tahun & $7(43,8 \%)$ & $4(33,3 \%)$ & \\
\hline 76-80 tahun & $0(00,0 \%)$ & $3(25,0 \%)$ & \\
\hline \multicolumn{4}{|l|}{ Kategori Jenis Kelamin } \\
\hline Laki-laki & $4(25,0 \%)$ & $7(58,3 \%)$ & $0,1^{* *}$ \\
\hline Perempuan & $12(75,0 \%)$ & $5(41,7 \%)$ & \\
\hline \multicolumn{4}{|l|}{ Kategori BMI } \\
\hline Underweight & $6(37,5 \%)$ & $2(16,7 \%)$ & $0,6^{*}$ \\
\hline Normoweight & $7(43,8 \%)$ & $8(66,7 \%)$ & \\
\hline Overweight & $1(6,3 \%)$ & $1(8,3 \%)$ & \\
\hline Obese & $2(12,5 \%)$ & $1(8,3 \%)$ & \\
\hline \multicolumn{4}{|c|}{ Kategori Tekanan Darah } \\
\hline Normal & $3(18,8 \%)$ & $2(16,7 \%)$ & $0,6^{*}$ \\
\hline Pre hipertensi & $6(37,5 \%)$ & $3(25,0 \%)$ & \\
\hline Hipertensi grade 1 & $6(37,5 \%)$ & $7(58,3 \%)$ & \\
\hline Hipertensi grade 2 & $1(6,3 \%)$ & - & \\
\hline \multicolumn{4}{|l|}{ Kategori GDS } \\
\hline Normal & $15(93,8 \%)$ & $11(91,7 \%)$ & $1,0 * *$ \\
\hline Diabetes mellitus & $1(6,3 \%)$ & $1(8,3 \%)$ & \\
\hline
\end{tabular}

* Pearson Chi Square; ** Fisher Exact Test

mengikuti penelitian dengan menandatangani inform consent.

Subjek yang memenuhi kriteria kemudian dibagi menjadi dua kelompok dengan menggunakan metode simple random sampling. Kelompok perlakuan mendapat suplementasi zink $40 \mathrm{mg}$ dalam $5 \mathrm{cc}$ sirup rasa pisang dan senam lansia sedangkan kelompok kontrol mendapat suplementasi plasebo sirup dan senam lansia. Pemberian suplementasi dilakukan setiap hari sebelum sarapan pagi selama delapan minggu sedangkan senam lansia dua kali seminggu selama delapan minggu. Senam lansia diberikan dua kali seminggu pada hari Selasa dan Kamis.Sebelum dan setelah penelitian, dilakukan analisa kadar albumin serum dan hemoglobin. Sampel berupa serum darah vena, pengukuran kadaralbumin serum dengan metode bromcresol green (BCG) sedangkan pengukuran kadar hemoglobin menggunakan metode sianmethemoglobin.

Variabel bebas dalam penelitian ini adalah pemberian suplementasi zink. Variabel terikat adalah kadar albumin serum dan hemoglobin. Data yang terkumpul dari lapangan terlebih dahulu di entry ke dalam file Microsoft Office Excel. Pengolahan data lebih lanjut menggunakan program komputer IBM SPSS Statistics version 20.

Uji hipotesis menggunakan uji Wilcoxon dan paired t-test. Perubahan kadar albumin dikatakan bermakna apabila nilai $p<0,05$.

Ethical clearance dari Komite Etik Penelitian Kesehatan (KPEK) Fakultas Kedokteran Universitas Diponegoro dan RSUP Dr. Kariadi Semarang No.42/EC/FK-RSDK/2015. 


\section{HASIL}

Selama penelitian, didapatkan 16 orang subjek penelitian pada kelompok perlakuan dan 15 orang subjek penelitian pada kelompok kontrol. Pada akhir penelitian, terdapat 3 orang drop out dari kelompok Kontrol karena meninggal dunia (dua orang) dan loss of follow up (satu orang) sehingga jumlah sampel akhir yang dianalisis adalah sebanyak 28 orang 16 orang kelompok perlakuan dan 12 orang kelompok kontrol. Pemberian suplementasi diharapkan dapat meningkatkan kadar albumin serum dan haemoglobin.

\section{Karakteristik subjek}

Karakteristik subjek penelitian dapat dilihat pada tabel 1. Berdasarkan uji Chi Square dan Fisher Exact Test, didapatkan tidak ada perbedaan subjek penelitian pada kedua kelompok penelitian $(p>0,05)$. Hal ini menujukkan bahwa subjek penelitian pada kedua kelompok penelitian adalah sama.

\section{Asupan nutrisi}

Asupan nutrisi lansia setiap hari berasal dari dapur Unit Rehabilitasi Sosial. Jenis makanan dan porsi ditentukan dan bersifat sama pada seluruh lansia di Unit Rehabilitasi Sosial. Rata-rata asupan gizi harian ditampilkan pada tabel 2 .

\section{Kadar albumin serum dan hemoglobin}

Perubahan kadar albumin subjek penelitian dapat dilihat pada gambar 1 dan 2 sedangkan perubahan rerata albumin dapat dilihat pada tabel 3 .

Perubahan kadar hemoglobin subjek penelitian dapat dilihat pada gambar 3 dan 4 sedangkan perubahan rerata albumin dapat dilihat pada tabel 4 .

\section{PEMBAHASAN}

Pada penelitian ini beberapa faktor yang dapat mempengaruhi kadar albumin serum dan hemoglobin seperti karakteristik subjek, aktivitas fisik dan asupan

\section{TABEL 2 \\ Rerata konsumsi zat gizi}

Jenis Gizi

Rerata Konsumsi

\section{Rekomendasi Kebutuhan Harian}

\section{Laki-Laki}

Perempuan

\section{Energi}

Karbohidrat

$1495,9 \pm 127,15 \mathrm{KKal}$

1900 KKal

$1550 \mathrm{Kkal}$

Protein

$202,3 \pm 28,04 \mathrm{~g}$

$309 \mathrm{~g}$

$252 \mathrm{~g}$

Lemak

$56,2 \pm 7,29 \mathrm{~g}$

$62 \mathrm{~g}$

$56 \mathrm{~g}$

Zink

$53,1 \pm 5,07 \mathrm{~g}$

$53 \mathrm{~g}$

$43 \mathrm{~g}$

$13 \mathrm{mg}$

$10 \mathrm{mg}$

Kadar Albumin Kelompok Perlakuan

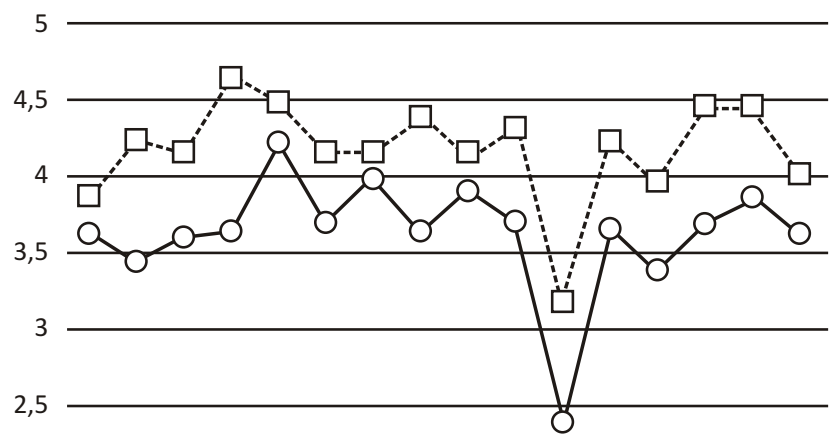

2

$\begin{array}{llllllllllllllll}1 & 2 & 3 & 4 & 5 & 6 & 7 & 8 & 9 & 10 & 11 & 12 & 13 & 14 & 15 & 16\end{array}$

$-\mathrm{O}-$ Pre Intervention
---- $\square---$ Pre Intervention

Sampel ke-

Gambar 1. Albumin kelompok perlakuan
Kadar Albumin Kelompok Kontrol

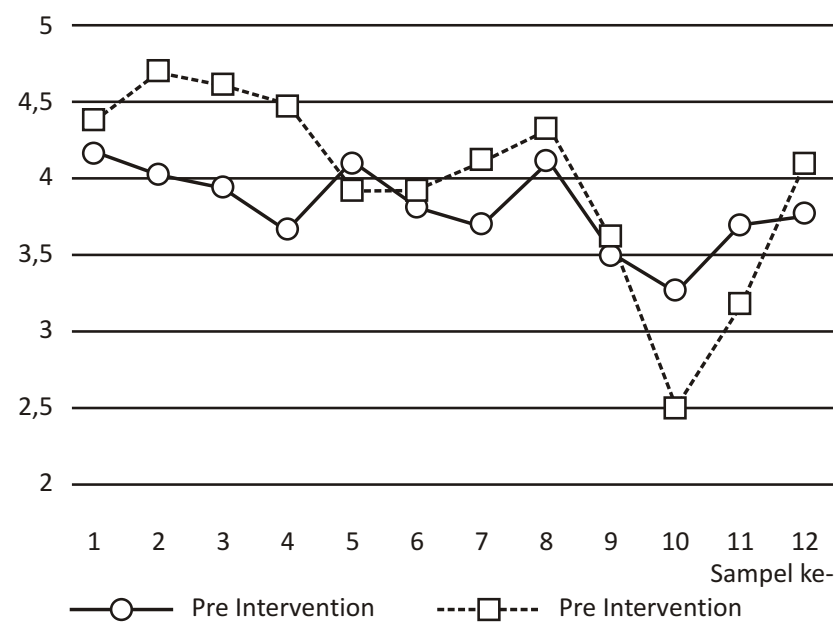

Gambar 2. Albumin kelompok kontrol 
Kadar Hemoglobin Kelompok Perlakuan

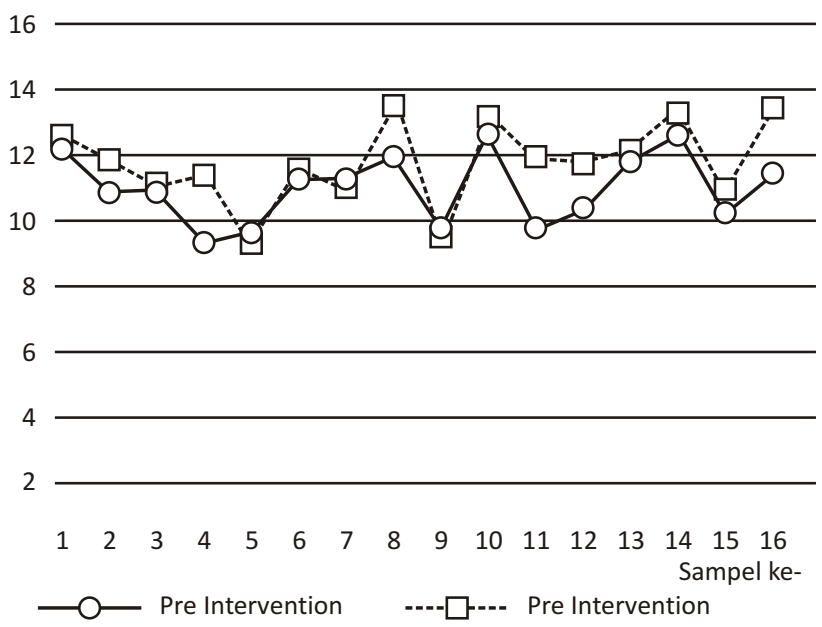

Gambar 3. Hemoglobin kelompok perlakuan
Kadar Hemoglobin Kelompok Kontrol

22

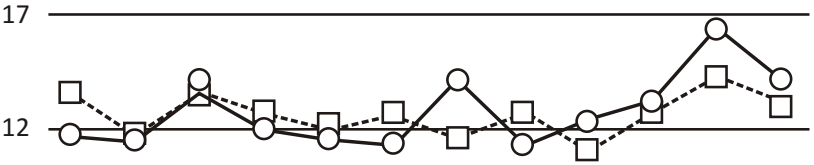

$\begin{array}{llllllllllll}1 & 2 & 3 & 4 & 5 & 6 & 7 & 8 & 9 & 10 & 11 & 12\end{array}$

- - Pre Intervention -.-- $\square---$ Pre Intervention

\section{TABEL 3 \\ Perubahan rerata kadar albumin kedua kelompok}

Kelompok

Albumin

Pre intervention

(Mean \pm SD)
Post Intervention

(Mean \pm SD)

\begin{tabular}{|c|c|c|c|c|}
\hline Perlakuan & $3,7 \pm 0,39$ & $4,2 \pm 0,34$ & $0,5 \pm 0,23$ & $<0,001^{*}$ \\
\hline Kontrol & $3,8 \pm 0,27$ & $4,0 \pm 0,61$ & $0,2 \pm 0,44$ & $0,175^{* *}$ \\
\hline
\end{tabular}

Gambar 4. Hemoglobin kelompok kontrol

*Wilcoxon test; ** Paired t-test

makanan sedapat mungkin diminimalisir agar tidak mempengaruhi hasil penelitian. Pada penelitian ini, subjek dipilih dari lingkungan dengan asupan nutrisi, jadwal aktivitas dan gaya hidup yang relatif sama. Gambaran karakteristik subjek menunjukkan tidak adanya perbedaan bermakna $(p>0,05)$ antara subjek kelompok perlakuan dan kelompok kontrol.

Hemoglobin merupakan sebuah tetramer yang terdiri dari 4 buah molekul globin yaitu dua alpha globin dua beta globin. Setiap unit globin mengandung sebuah molekul heme. Molekul heme terdiri atas cincin porfirin yang mengandung empat molekul pyrrole (tetrapyrrole) yang berbentuk melingkar. 6,7

Nutrisi makanan pada lansia yang seringkali tidak mencukupi kebutuhan tubuh untuk menjaga kesehatan berakibat pada berkurangnya nutrisi mikro dan menurunnya daya tahan tubuh. Audrey Varin, dkk tahun 2013 dan Tolunay Beker Aydemir, dkk meneliti bahwa zink merupakan nutrisi yang berperan dalam sistem imun sebagai regulator sitokin inflamasi dan menginisiasi sel T. Selain itu zink telah dikenal luas dalam perannya di lebih dari 300 enzim yang salah satunya merupakan enzim dalam sintesis hemoglobin. Namun pada lansia, pemenuhan kebutuhan zink hanya
$50 \%$ dari angka kebutuhan gizi dalam sehari sehingga perlu tambahan suplementasi zink. ${ }^{9,10}$

Pemberian suplementasi zink terbukti dapat meningkatkan rerata kadar hemoglobin sebesar $0,7 \pm 0,114 \mathrm{~g} / \mathrm{dL}(p=0,002)$ sedangkan pada kelompok kontrol rerata kadar hemoglobin cenderung turun sebesar 0,2 $\pm 0,61 \mathrm{~g} / \mathrm{dL}(p=0,667)$. Hal ini sesuai dengan penelitian Ratna Candra Dewi 2008 pada ibu hamil menunjukkan bahwa kadar hemoglobin meningkat $(p<0,05) \cdot{ }^{11}$ Pada Penelitian Listyani Hidayati, dkk tahun 2009 dan Handayani Siwi 2008 menunjukkan kenaikan $\mathrm{Hb}$ yang bermakna $(p<0,05) \cdot{ }^{12,13}$

Pada penelitian tikus yang mengalami anemia dan imunosupresi karena diinfeksi Trypanosoma brucei diberikan suplementasi zink untuk selanjutnya dinilai dari berbagai parameter hematologi oleh J.I. Eze, dkk 2015, zink diketahui berfungsi sebagai kofaktor enzim Aminolevulic acid (ALA) dehidrgenase. Metaloenzim ini berperan pada sintesis heme untuk mempercepat kondensasi dua molekul ALA dan membentuk porphobilinogen (PGB). ${ }^{14}$

Zink merupakan elemen esensial tubuh yang mempuyai fungsi katalitik dan fungsi struktural. Pada fungsi katalitik, zink merupakan komponen dari 


\section{TABEL 4}

Perubahan rerata kadar albumin kedua kelompok

Kelompok

\section{Pre intervention \\ (Mean \pm SD)}

\section{Albumin}

Post Intervention

(Mean \pm SD) $\boldsymbol{p}$

\section{$\Delta$ albumin \\ (Mean \pm SD)}

\begin{tabular}{lllll}
\hline Perlakuan & $11,2 \pm 1,10$ & $11,9 \pm 1,24$ & $0,7 \pm 0,114$ & $0,002^{*}$ \\
Kontrol & $12,8 \pm 1,61$ & $12,6 \pm 0,95$ & $0,2 \pm 0,61$ & $0,002^{*}$
\end{tabular}

* Paired t-test

Biosintesis Hemoglobin

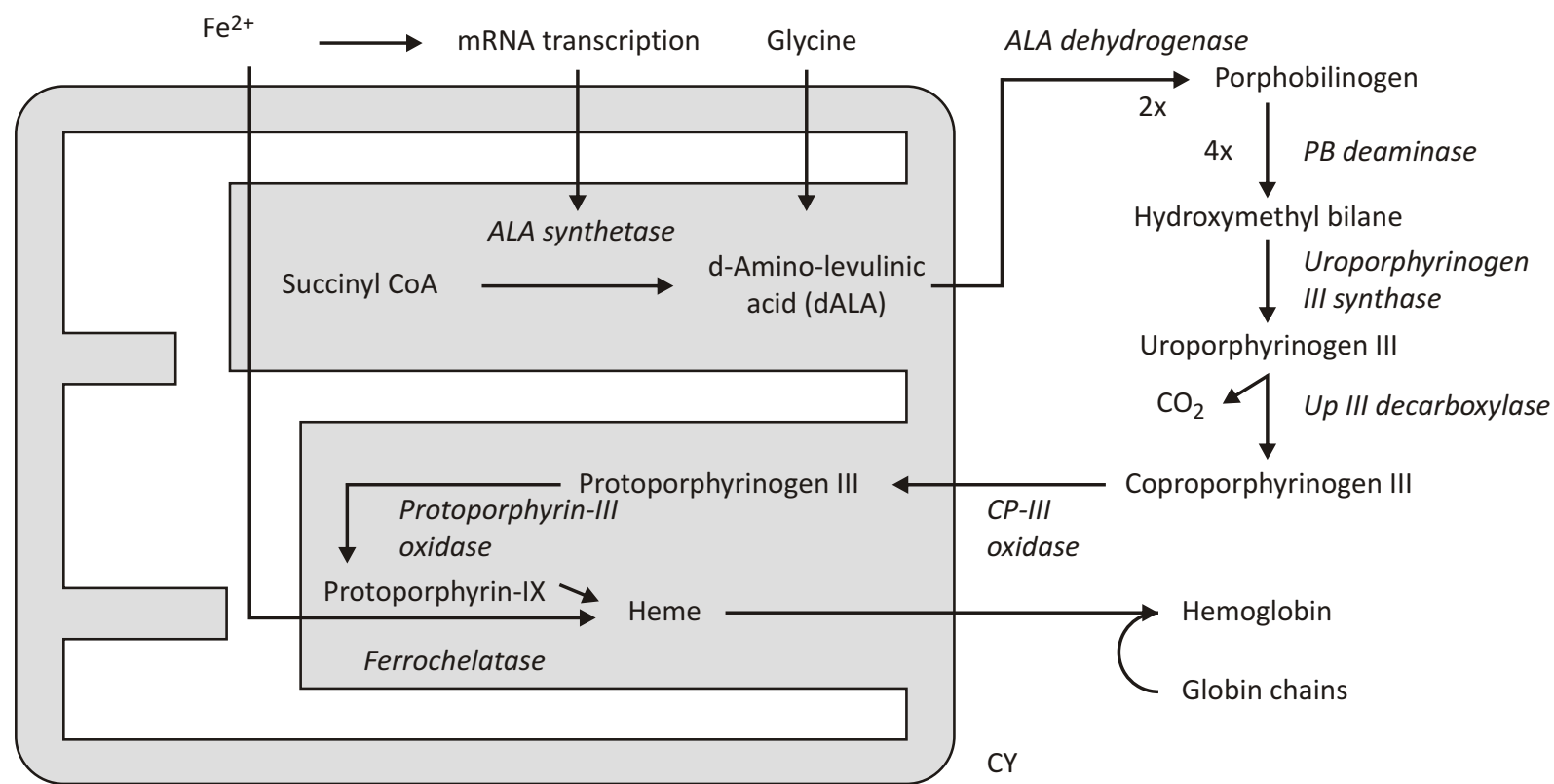

Mitokondria

Sitoplasma

Gambar 5. Biosintesis Heme ${ }^{8}$

metaloenzim yang berfungsi pada proses metabolisme. ${ }^{15,16}$ Katalitik zink berperan dalam mengaktivasi substrat sebagai asam Lewis yang mengikat elektron molekul. ${ }^{17}$

Proses katalitic enzim terbagi menjadi dua tahap yaitu polarisasi grup karboksil dan deprotonisasi oleh nucleophile air.16

a) Tahap pertama,zink yang terikat dengan enzim dan gugus hidroksil menyerang gugus karboksil dari $\mathrm{CO}_{2}$ untuk membentuk ikatan zink bicarbonate. Selanjutnya, bikarbonat digantikan oleh air pada saat berikatan dengan ligan.

b) Tahap kedua, $\mathrm{H}^{+}$ditransfer dari zink yang terikat air menuju eksternal buffer. Hasil akhir yang akan didapat adalah zink hidroksida $\left(\mathrm{ZnOH}^{-}\right)$. $\mathrm{ZnOH}^{-}$ harus dalam bentuk inaktif karena ion $\mathrm{H}^{+}$ mempunyai aktifitas tinggi untuk berikatan dengan substrat lain untuk itu diperlukan water nuclephile sebagai basa general yang diaktivasi oleh His231. ${ }^{15-17}$

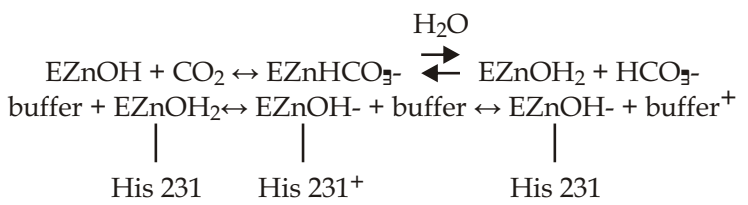

Penelitian ini juga didapatkan hasil adanya peningkatan rerata kadar albumin pada kelompok perlakuan sebesar $0,5 \pm 0,23 \mathrm{~g} / \mathrm{dl}$ atau sebesar 13,51\% dari kadar awal sedangkan pada kelompok kontrol rerata kadar albumin meningkat sebesar 0,2 $\pm 0,61 \mathrm{~g} / \mathrm{dl}$ atau sebesar 5,26\% dari kadar awal. Berdasarkan hasil uji statistik, kadaralbumin kelompok perlakuan mengalami peningkatan bermakna dibandingkan pada kelompok kontrol.

Hasil ini sejalan dengan penelitian Ghaemmaghami (2010), yang melaporkan terjadinya peningkatan kadar albumin $(p<0,05)$ serta penurunan kejadian kelainan gastrointestinal seperti mulut kering, mual dan hypoguesia $(p<0,05)$ setelah pemberian 
suplementasi zink dosis $220 \mathrm{mg}$ perhari selama 60 hari pada pasien hemodialisa. Pada penelitian tersebut, aktivitas fisik serta jenis dan jumlah asupan makanan subjek penelitian tidak dikontrol oleh peneliti sehingga peningkatan kadar albumin mungkin terjadi akibat pengaruh peningkatan asupan makanan akibat penurunan kelainan gastrointestinal. ${ }^{18}$

Argani (2014) melaporkan adanya perbaikan status gizi berupa peningkatan kadar albumin serum dari hipoalbuminemia menjadi kadar normal dan peningkatan BMI secara bermakna setelah pemberian suplementasi zink dengan dosis $100 \mathrm{mg}$ perhari selama 60 hari. $^{19}$

Asupan zink yang tidak adekuat dalam waktu berkepanjangan dapat memicu timbulnya defisiensi zink. Prasad (2014) memaparkan bahwa kondisi defisiensi zink memicu aktivasi sel monosit dan makrofag sehingga terjadi peningkatan pembentukan sitokin pro-inflamasi. ${ }^{20}$ Peningkatan sitokin proinflamasi akan memperburuk status stres oksidatif dalam tubuh lansia dan menyebabkan peningkatan oksidasi protein terutama albumin melalui proses glikasi dan terjadi peningkatan pembentukan AGE. ${ }^{21}$

Penelitian yang dilakukan oleh Guo (2013), melaporkan adanya perbaikan status stres oksidatif berupa penurunan jumlah radikal bebas (ROS dan MDA) serta peningkatan aktivitas antioksidan enzimatik (SOD dan GPx) setelah pemberian suplementasi zink selama dua bulan. ${ }^{22}$ Hasil penelitian tersebut menguatkan pendapat Himoto (2007), bahwa pemberian suplementasi zink dapat menghambat stres oksidatif serta memiliki efek sitoprotektif pada sel hati dengan cara menginduksi $\mathrm{Zn}$-metalloenzym yang berfungsi sebagai scavenger ROS, menurunkan iron overload, dan menginduksi pembentukan heat shock protein-72 (HSP72). ${ }^{23}$

Pemberian suplementasi zink juga berpengaruh terhadap reaksi glikasi albumin. Baraka-Vidot (2014) dalam studinya melaporkan, ion zink dapat memicu inhibisi reaksi glikasi pada albumin secara ex-vivo serta menurunkan pembentukan produk glikasi sebesar $48 \% .{ }^{24}$ Berdasarkan penelitian sebelumnya, AGE diketahui terlibat dalam proses patologi berbagai penyakit di dalam tubuh seperti diabetes mellitus, retinopati, nefropati, alzheimer, neuropati dan PJK sehingga penurunan oksidasi albumin dan produk glikasinya setelah pemberian suplementasi zink diharapkan dapat meningkatkan kesehatan lansia. ${ }^{21}$

\section{SIMPULAN}

Pemberian suplementasi zink $40 \mathrm{mg}$ selama delapan minggu dapat meningkatkan kadar albumin serum dan hemoglobin lansia. Penelitian lebih lanjut mengenai pemberian suplementasi zink pada populasi lansia yang lebih luas dengan sampel yang lebih banyak dan waktu yang lebih lama perlu dilakukan untuk mengetahui efek pemberian suplementasi zink serta mengetahui toleransi pemberian suplementasi zink khususnya pada populasi lansia.

\section{DAFTAR PUSTAKA}

1. Nicholson JP, Wolmarans MR, Park GR. The role of albumin in critical illness. Br J Anaesth. 2000; 85(4):599-610

2. Badan Perencanaaan Pembanguan Nasional Badan Pusat Statistik. Proyeksi penduduk Indonesia 2010-2035. Jakarta: Badan Pusat Statistik. 2013

3. Mendoza-Núñez VM, Ruiz-Ramos M, Sánchez-Rodríguez MA, Retana-Ugalde R, Muñoz-Sánchez JL. Aging-Related Oxidative Stress in Healty Human. Tohoku J. Exp. Med. 2007; 213;261-8.

4. Chasapis CT, Loutsidou AC, Spiliopoulou CA, Stefanidou ME. Zinc and human health: an update. Arch Toxicol. 2012; 86(4):521-34

5. BhagavanNV. Metabolisme of Iron and Heme dalan Medical Biochemistry. Academic Press: 2002; 29:685

6. Experiment X Blood and Hemoglobin [internet]. [cited 2015 Jan 15]. Avaliable from : http://courses.chem.indiana.edu/ c122/documents/Experiment10_BloodandHemoglobin.pdf.

7. Havard university. Hemoglobin Synthesis. [internet]. 2002. [cited 2015 Jan 15]. Avaliable from: http://sickle.bwh.harvard.edu/hbsynthesis.html

8. Reddaway . Lead: History Repeating Itself. [internet]. 2009. [cited 2015 Jan 27]. Avaliable from: faculty.virginia.edu/metals/cases/reddaway3.html

9. VarinA, Larbi A, George V. Dedoussis, Kanoni S, Jajte J, et al. In vitro and in vivo effects of zinc on cytokine signalling in human T cells. Experimental gerontology [internet].2008. [cited 2015 jun 12]: 43(5): 472-482. Avaliable from: Science direct

10. Aydemir TB, Blanchard RK, Cousins RJ. Zinc supplementation of young men alters metallothionein, zinc transporter, and cytokine gene expression in leukocyte populations. Proceedings of the National Academy of Sciences of the United States of America. internet].2006. [cited 2015 Jun 12]: 103(6): 1699-1704. Avaliable from: PMC

11. Dewi RC. Pengaruh suplementasi tablet tambah darah (ttd), seng, dan vitamin a terhadap kadar hemoglobin ibu hamil. [internet]. 2008. [cited 2015 Jun 8]: 3(1):. Avaliable from: Media Kesehatan Masyarakat

12. Hidayati l, Dasuki S, Hanwar D, Prasetyaningrum J. Pengembangan model suplementasi fe dan zn dalam bentuk permen pada anak sekolah dasar yang anemia. Jurnal Kesehatan [internet]. 2009. [cited 2015 Jun 8]: 2(2): 769-777. Avaliable from: publikasiilmiah.ums.ac.id

13. Handayani S. Pengaruh suplementasi besi dan seng terhadap kadar hemoglobin dan prestasi belajar pada siswa sekolah dasar di kecamatan gemolong kabupaten sragen tahun 2008. [disertation]. Semarang (Indonesia). Universitas Diponegoro.2008

14. Eze, J. I., L. C. Ayogu, F. O. Abonyi, and U. U. Eze. The beneficial effect of dietary zinc supplementation on anaemia and immunosuppression in Trypanosoma brucei infected rats.Experimental parasitology[internet].2015. [cited 2015 Jun 8]154:87-92. Avaliable from: Sciencedirect

15. McCall KA, Huang CC and Fierke CA. Zinc and Health: Current Status and Future Directions Function and Mechanism of Zinc Metalloenzymes. [internet]. 2000. [cited 2015 Jan 18]. Available from:jn Nutrition

16. Radboud University Nijmegen. Catalytic Mechanism of Zinc Enzim. [internet]. [cited 2015 Jan 18]. Available from:http:/ / swift.cmbi.ru.nl/teach /B2/tln/chapter31.html 
17. 17Lee YM, Lim Carmay . Physical Basis of Structural and Catalytic Zn-Binding Sites in Proteins. [internet]. 2008. [cited 2015 Jan 18]:379(3);545-553. Avaliable from: Science Direct

18. Ghaemmaghami J, Mahdavi R, Faramarzi E, Mohammadpour N, Argani H. Does zinc supplementation improve dietary intake, symptoms of eating problems, and serum zinc levels in hemodialysis patients. Dial. Transplant. 2010;39:530-533

19. Argani H, Mahdavi R, Ghorbani-haghjo A, Razzaghi R, Nikniaz L, Gaemmaghami SJ. Effects of zinc supplementation on serum zinc and leptin levels, BMI, and body composition in hemodialysis patients. J Trace Elem Med Biol. 2014; 28(1):35-8

20. Prasad AS. Zinc: an antioxidant and anti-inflammatory agent: role of zinc in degenerative disorders of aging. J Trace Elem Med Biol. 2014; 28(4):364-71
21. Arasteh A, Farahi S, Habibi-Rezaei M, Moosavi-Movahedi AA. Glycated albumin: an overview of the In Vitro models of an In Vivo potential disease marker. J Diabetes Metab Disord. 2014; 13:49

22. Guo CH, Chen PC, Hsu GS, Wang CL. Zinc supplementation alters plasma aluminum and selenium status of patients undergoing dialysis: a pilot study. Nutrients. 2013; 5(4):1456-70

23. Himoto T, Hosomi N, Nakai S, Deguchi A, Kinekawa F, Matsuki M, et all. Efficacy of zinc administration in patients with hepatitis $C$ virus-related chronic liver disease. Scand J Gastroenterol. 2007;42(9):1078-87

24. Baraka-Vidot J, Navarra G, Leone M, Bourdon E, Militello V, Rondeau P. Deciphering metal-induced oxidative damages on glycated albumin structure and function. Biochim Biophys Acta. 2014;1840(6):1712-24 